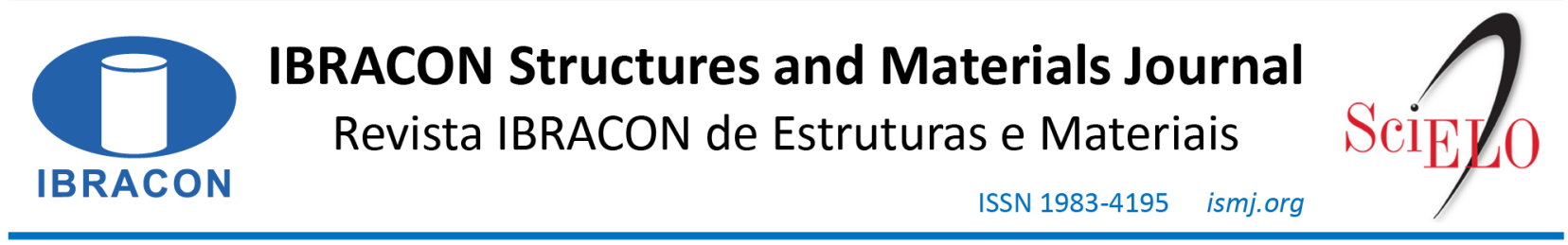

ORIGINAL ARTICLE

\title{
Partial replacement of Portland cement with industrial glass waste in mortars
}

\section{Substituição parcial de cimento Portland por resíduo moído de vidro industrial em argamassas}

\author{
Raduan Krause Lopes ${ }^{\mathrm{a}}$ (it) \\ Jayne Carlos Piovesan ${ }^{\mathrm{b}}$ \\ Bernardo Fonseca Tutikian ${ }^{\mathrm{c}}$ \\ Atilio Efrain Bica Grondona ${ }^{c}$ (D)
}

${ }^{a}$ Fundação Universidade Federal de Rondônia - UNIR, Departamento de Engenharia Civil, Porto Velho, RO, Brasil

${ }^{\mathrm{b} C e n t r o ~ U n i v e r s i t a ́ r i o ~ S a ̃ o ~ L u c a s ~-~ U N I S L, ~ P o r t o ~ V e l h o, ~ R O, ~ B r a s i l ~}$

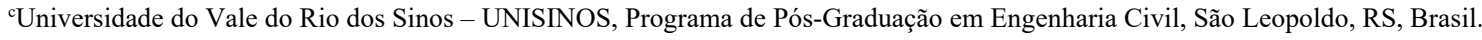

Received 14 November 2019

Accepted 29 June 2020

\begin{abstract}
The necessity to reduce the consumption of cement in cementitious composites is a worldwide concern and the partial replacement of cement with industrial waste has gathered considerable interest. One type of industrial waste is glass, which is rich in amorphous silica but can present problems with its use due to the alkali-silica reaction (ASR). The objective of this study was to analyze the compressive strengths of mortars using ground glass residue (GLR). Milling times of $16 \mathrm{~h}$ and $32 \mathrm{~h}$ were conducted and GLR tested in cement substitutions of 10 w.t. $\%, 15$ w.t. $\%$ and 20 w.t. $\%$. A statistical analysis was performed to verify which factors affected mortar strength. The mitigating effect of GLR in ASR was also tested. Results showed that milling time did not affect resistance significantly but w.t.\% substitution did. The substitution of 20 w.t.\% proved to provide the best result as it was statistically equal to the standard mixture.
\end{abstract}

Keywords: ground glass residue (GLR), mortar, pozzolanic activity, alkali-silica reaction (ASR).

Resumo: A busca pela redução do consumo de cimento em compósitos cimentícios se mostra uma preocupação mundial, e a substituição parcial do cimento por resíduos industriais tem ganhado impulsão. Um desses materiais é o vidro, material rico em sílica amorfa, mas que pode apresentar problemas em sua utilização, devido à reação álcali sílica (RAS). O objetivo da pesquisa foi analisar as resistências à compressão de argamassas com uso de resíduo moído de vidro (RMV). Foram testados dois tempos de moagem para RMV, 16 e 32 horas, bem como percentuais de 10, 15 e $20 \%$ de substituição em massa de cimento por RMV. Uma análise estatística foi realizada para verificar quais fatores interferiam na resistência das argamassas. $\mathrm{O}$ efeito mitigador do RMV também foi testado quanto à RAS. Os resultados mostraram que o tempo de moagem não foi significativo para resistência, mas os percentuais de substituição foram. O percentual de $20 \%$ mostrouse o melhor, uma vez que foi estatisticamente igual ao traço padrão.

Palavras-chave: resíduo moído de vidro (RMV), argamassa, atividade pozolânica, reação álcali sílica (RAS).

How to cite: R. K. Lopes, J. C. Piovesan, B. F. Tutikian, and A. E. B. Grondona, "Partial replacement of Portland cement with industrial glass waste in mortars," Rev. IBRACON Estrut. Mater., vol. 14, no. 2, e14214, 2021, https://doi.org/10.1590/S1983-41952021000200014

\section{INTRODUCTION}

Currently, one of the greatest challenges in construction is to merge material performance with reductions in environmental impact and cost of production. According to Higuchi [1], the environmental impact of concrete and mortar production are enormous, especially with respect to Portland cement and the environmental impact of its 
production. Cement remains one of the main materials needed in construction and its production also consumes a significant amount of energy and contributes greatly to carbon dioxide emissions [2].

More recently, the environmental impacts of construction have been acknowledged and studies regarding sustainability have come to the forefront of this area. Much of this work has been focused in reducting in the quantity of cement used. To this end, Sales et al. [3] noted that cement substitution with solid residues has been used as an alternative. Several studies have been conducted to improve the performance, durability, physical and chemical properties, hydration and microstructure of mixtures mortar and concrete that incorporate residues [2].

Glass, as noted by Gómez-Soberón et al. [4], is a different type of recyclable material available in great quantities to supply the demand for substitute construction materials. Glass itself is also a solid residue with several environmental impacts: it is non-biodegradable so it permanently occupies landfills and associated pollution can be pervasive in the air, water and soil [2], [4]. A possible solution would be the use of glass in concrete and mortar mixtures since it has chemical composition and phases similar to traditional supplementary cementitious materials (SCMs) [5]. Higuchi [1] noted that the chemical composition and reactivity of glass as a SCM can improve chemical stability, water resistance and durability of concrete. However, other studies noted that the size of glass particle has an effect in concrete and mortar mixtures. Better results were obtained with glass residue particles in the microscale range [1], [4]-[6] and smaller particles have better activation and pozzolanic behavior [3], [7].

Special considerations must be taken so that an alkali silica reaction (ASR) does not occur when glass residue is incorporated in mortar and concrete mixtures. As noted by Azevedo et al. [8], glass and cement are chemically incompatible. Alkaloids present in Portland cement and vitreous silica react under humidity to form an ASR. This reaction can be reduced with the use of cements with low alkali content or which contains materials that inhibit or minimize the reaction, such as pozzolans and slag. Yet, other studies reported that glass residue used as supplemental cementitious material (SCM) or fine aggregate in concrete and mortar do not undergo ASR if the residue particles are of a size below $100 \mu \mathrm{m}[8]-[9]$.

With these in mind, the objective of this study was to evaluate the partial substitution of Portland cement with ground glass residue (GLR) in mortars. Milling time and w.t.\% substitution were tested with respect to inhibiting effects on ASR and compression strength.

\section{MATERIALS AND METHODOLOGY}

\subsection{Materials}

Portland cement CP II Z - 32 was used in mortar mixing ratios of. The average particle size of cement was measured with laser granulometry in order to ascertain the proper level of substitution with GLR. This work was performed in the Mineral Analysis Laboratory (LAMIN) of CPRM at Manaus/AM with a Malvern Mastersizer laser particle analyzer. Additionally, a thermogravimetric analysis was conducted to verify potential physiochemical changes in cement samples. This allowed the determination of decomposition reactions occurring in substances with respect to variations in mass and gradual temperature increases. This part of the work was conducted at the Physiochemical Test Laboratory at FT/UFAM with a TA Instrument thermal analysis system model SDT Q600. The cement sample of approximately $12 \mathrm{mg}$ was subjected to a heating rate of $10^{\circ} \mathrm{C} / \mathrm{min}$ until a final temperature of $950{ }^{\circ} \mathrm{C}$ with an $\mathrm{N} 5.0$ gas flow of 30 $\mathrm{ml} / \mathrm{min}$ in an uncovered $90 \mu \mathrm{l}$ aluminum crucible.

Chemical composition of cement was obtained through X-ray fluorescence (XRF) with a PANalytical spectrometer model EPSILON 3 XL in the Physiochemical Test Laboratory at FT/UFAM. Knowledge of the exact chemical composition of cement is paramount in identifying compounds that affect the hydration process and strength of the cementitious matrix. The crystallographic formations were obtained from X-ray diffraction (XRD) with a Brucker model D2 PHASER diffractometer in the Nanomaterial Characterization and Synthesis Laboratory (LSCN) at IFAM. Local tap water and a polycarboxylate-based 3rd generation superplasticizer with characteristics shown in Table 1 were also used.

Table 1. Polycarboxylates-vased plasticizer additive characteristics

\begin{tabular}{ccccccc}
\hline Type & Chemical base & Aspect & Color & pH & Density (g/cm $\left.\mathbf{c m}^{\mathbf{3}}\right)$ & Solid \% \\
\hline $\begin{array}{c}3^{\text {rd }} \text { generation } \\
\text { superplasticizer }\end{array}$ & $\begin{array}{c}\text { Polycarboxylate ether } \\
\text { (PCE) }\end{array}$ & Liquid & $\begin{array}{c}\text { Murky } \\
\text { white }\end{array}$ & 5 to 7 & 1.066 & $28.50-31.50$ \\
\hline
\end{tabular}


Sand was taken from the Jamari river and the fine aggregate obtained from it has the characteristics shown in Table 2. Specific mass and apparent specific mass were $2.67 \mathrm{~kg} / \mathrm{dm}^{3}$ and $1.45 \mathrm{~kg} / \mathrm{dm}^{3}$, respectively. These values and the measured fineness modulus were similar to other works [1], [2]. Powdered material present was within the 3 w.t.\% to 5 w.t.\% recommended margin specified in NBR NM 46:2003 [12]. Organic impurities were also within the limits set by the color scale of NBR NM 49:2001 [13]. Clay and fracturing material were at the 1.5 w.t.\% limit of use set in NBR 7218:2010 [15].

Table 2. Fine aggregate characterization.

\begin{tabular}{cccc}
\hline Test & Norm & Units & Results \\
\hline Specific mass & NBR NM 52:2009 [10] & $\mathrm{kg} / \mathrm{dm}^{3}$ & 2.67 \\
\hline Apparent specific mass & NBR NM 45:2006 [11] & $\mathrm{kg} / \mathrm{dm}^{3}$ & 1.45 \\
\hline Powdered material \% & NBR NM 46:2003 [12] & $\%$ & 4.70 \\
\hline Organic impurities & NBR NM 49:2001 [13] & ppm & 300 \\
\hline Fineness modulus & NBR NM 248:2003 [14] & - & 2.69 \\
\hline Maximum diameter & NBR NM 248:2003 [14] & mm & 2.40 \\
\hline Clay and fracturing material $\%$ & NBR 7218:2010 [15] & $\%$ & 1.50 \\
\hline
\end{tabular}

These results showed that the fine aggregate of this study was suitable for mortar use. The granulometric distribution of fine aggregate was determined in accordance with NBR NM 258:2003 [14]. Results, shown in Figure 1, present a good distribution within optimal limits, according to NBR 7211:2009 [16].

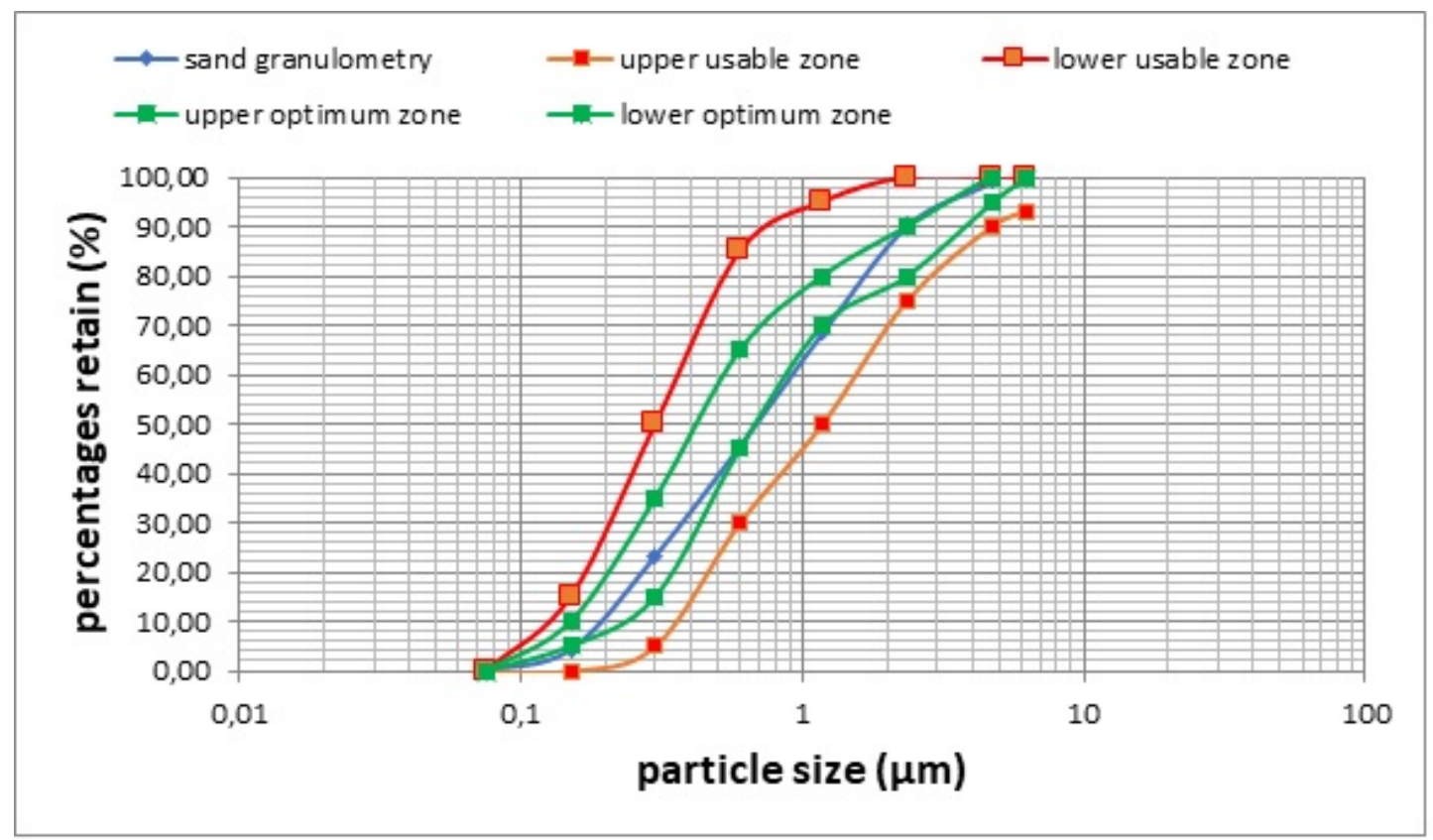

Figure 1. Granulometric curve of fine aggregate

\subsection{Methodology}

\subsubsection{Ground glass residue (GLR) acquisition, preparation and characterization}

Glass residue was acquired from Guaporé Indústria e Comércio de Vidros Ltda. from the east side of Porto Velho - RO. The supplier is responsible for supplying $70 \%$ of commercial glass in the state of Rondônia. The residue is produced from the cutting and polishing processes of commercial glass which is performed with water cooling. Glass 
dust and water are collected in troughs and deposited in decanting tanks. Water is reused while glass is collected in plastic bags and sent to landfills. Glass residue in paste form was collected for this study, dried in the laboratory at 105 ${ }^{\circ} \mathrm{C}$ for $24 \mathrm{~h}$, disentangled and sifted through a $600 \mu \mathrm{m}$ sieve. The dried material was placed in a mill with 30 ceramic balls: 7 of them with diameters of $10 \mathrm{~cm}$ and 23 with diameters of $5 \mathrm{~cm}$. Two milling times were used: $16 \mathrm{~h}$ and $32 \mathrm{~h}$ which were selected based on GRL preparation procedures of Sousa Neto [17].

The milling efficiency was verified with laser granulometry. Chemical composition and crystallographic formations of GLR were analyzed with XRF and XRD, respectively. These same procedures were also applied to confirm the properties of Portland cement CP II-Z-32.

\subsubsection{Fresh and cured mortar evaluation}

Samples of mortar bars were produced to verify the mitigation of the alkali-silica reaction with a mixing ratio of 1:2.25:0.47 in mass with cement substituted with GLR in proportions of 10 w.t. $\%, 20$ w.t. $\%, 30$ w.t. $\%$ and 40 w.t.\%. These large levels were selected to increase the effect of the substitution and to accentuate the effect of the milling times (16 and 32 hours). Portland cement CP V-ARI was purposely used in the mortar due to its high alkali content. The potential mitigation of ASR was evaluated following the procedures of Part 5 of NBR 15577:2018 [18]. An accelerated mortar test was conducted with samples immersed in a sodium hydroxide solution and heated to $80{ }^{\circ} \mathrm{C}$, which causes expansion. Depending on the degree of expansion, the material could be considered as a having a mitigating effect on ASR. Expansion measurements were taken after the 3rd day and further readings were taken after 16 days and 30 days. Complementary studies were conducted on the pozzolanic potential of GLR: chemical analysis following NBR 12653:2014 [19] and physical analysis following NBR 5752:2014 [20].

Further test samples were produced based on Paiva [21]. A reference test control mixing ratio of 1:2:0.4 in mass was produced for compression resistance tests at 7 days and 28 days of curing. For these samples, GLR substitution was of 10 w.t. $\%, 15$ w.t. $\%$ and 20 w.t. $\%$. These values were selected based on results of other studies that noted that a 20 w.t. $\%$ to 25 w.t. $\%$ were ideal. Samples were further classified in accordance to GLR milling times of $16 \mathrm{~h}$ and $32 \mathrm{~h}$ $(\mathrm{A}=16 \mathrm{~h}$ and $\mathrm{B}=32 \mathrm{~h})$. These samples incorporated a superplasticizer additive to maintain a minimum initial consistency of $200 \mathrm{~mm}$. Consistency measurements followed the procedures of NBR 13276:2016 [22]. The composition and mixing ratio of these test samples are shown in Table 3.

Table 3. Mixing ratios of samples tested.

\begin{tabular}{|c|c|c|c|c|c|c|c|}
\hline \multirow{2}{*}{ Ratio/Test Sample } & TC & T10A & T10B & T15A & T15B & T20A & T20B \\
\hline & \multicolumn{7}{|c|}{ Quantity of Material $\left(\mathrm{kg} / \mathrm{m}^{\mathbf{3}}\right)$} \\
\hline Cement & 544.12 & 489.71 & 489.71 & 462.50 & 462.50 & 435.30 & 435.30 \\
\hline Glass & 0.00 & 54.41 & 54.41 & 81.62 & 81.62 & 108.82 & 108.82 \\
\hline Sand & 1088.24 & 1088.24 & 1088.24 & 1088.24 & 1088.24 & 1088.24 & 1088.24 \\
\hline Water & 217.65 & 217.65 & 217.65 & 217.65 & 217.65 & 217.65 & 217.65 \\
\hline Plasticizer & 0.54 & 0.65 & 0.65 & 0.76 & 0.76 & 0.87 & 0.87 \\
\hline $\begin{array}{c}\text { water/cementitious material } \\
\text { ratio }\end{array}$ & 0.40 & 0.40 & 0.40 & 0.40 & 0.40 & 0.40 & 0.40 \\
\hline
\end{tabular}

All test samples were produced in a Motomil 120-liter mechanical mixer. Five cylindrical test bodies measuring 5 $\mathrm{cm} \times 10 \mathrm{~cm}$ were produced for each mixing ratio. Concrete was poured in two layers with 15 strokes of manual compacting each layer. Samples were demolded after $24 \mathrm{~h}$ and submerged in a water tank until rupturing. Mechanical grinding was used to smooth out the surfaces of the test samples.

Compression strength tests were conducted in an Instrom apparatus model EMIC 23-100 in the Structural and Mechanical Tests Laboratory (LAEEM) of the Civil Engineering department of UNIR. The load velocity was of 0.45 $\mathrm{MPa} / \mathrm{s}$ as recommended by NBR 5739:2018 [21].

Axial compression strength results were validated with a $2 \times 3$ statistical model $(2$ ground times and 3 w.t.\% substitution values) and the additional test control sample. An ANOVA analysis was performed with Assistant 7.7 commercial software and the averages were compared in Tukey tests $(\mathrm{P} \leq 0.05)$. 


\section{RESULTS AND DISCUSSION}

\subsection{GLR characterization}

Following $16 \mathrm{~h}$ and $32 \mathrm{~h}$ milling times, the granulometric distribution of GLR samples was analyzed with a laser particle analyzer. Figure 2 presents granulometry results for both grounds alongside Portland cement CP II-Z-32.

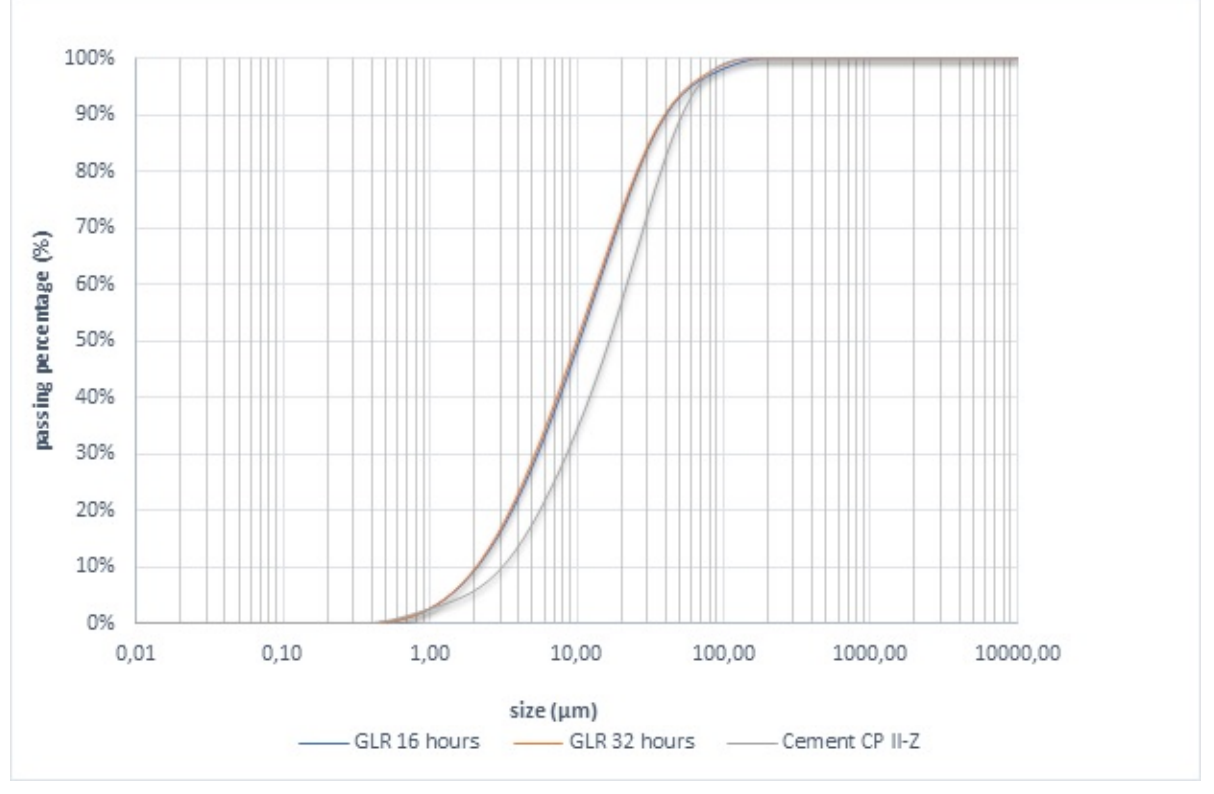

Figure 2. Granulometric distribution of both types of GLR milling and Portland cement CP II-Z

Results show that there were no significant differences in particle size between the milling times of $16 \mathrm{~h}$ and $32 \mathrm{~h}$. This attests both to the efficiency of the 16-hour ground as well as the limits of the equipment to further reduce particle size. More specifically, sizes $\mathrm{D}(90), \mathrm{D}(50)$ and $\mathrm{D}(10)$ after $16 \mathrm{~h}$ were of $40.38 \mu \mathrm{m}, 10.44 \mu \mathrm{m}$ and $2.11 \mu \mathrm{m}$, respectively. In comparison, the corresponding $32 \mathrm{~h}$ sizes were of $39.65 \mu \mathrm{m}, 10.04 \mu \mathrm{m}$ and $2.08 \mu \mathrm{m}$, respectively. The average $\mathrm{D}(50)$ of cement particles was $16.67 \mu \mathrm{m}$ and since GLR particles were smaller than cement, they should have a filler effect and cause improved compaction of the mixture.

Table 4 presents the GLR chemical composition obtained from XRF. It can be seen that the GLR was classified as soda-lime glass containing sodium and calcium. The 74.07 w.t.\% silica content pointed a pozzolanic potential. As noted in NBR 12653:2014 [19], a material may be classified as pozzolanic if the sum of $\mathrm{SiO} 2+\mathrm{Al} 2 \mathrm{O} 3+\mathrm{Fe} 2 \mathrm{O}$ is greater than 70 w.t.\%.

Table 4. Chemical composition of GLR and Portland cement CP II-Z-32

\begin{tabular}{ccc}
\hline Chemical compond & Ground glass residue - GLR (w.t.\%) & $\begin{array}{c}\text { Portland cement CP II- } \\
\text { Z-32 (w.t.\%) }\end{array}$ \\
\hline $\mathrm{SiO}_{2}-$ silicon dioxide & 74.07 & 22.94 \\
\hline $\mathrm{CaO}-$ calcium oxicde & 13.27 & 57.61 \\
\hline $\mathrm{Na}_{2} \mathrm{O}-$ sodium oxide & 7.94 & - \\
\hline $\mathrm{MgO}-$ magnesium oxide & 1.93 & 3.99 \\
\hline $\mathrm{Al}_{2} \mathrm{O}_{3}-$ aluminum oxide & 0.99 & 5.60 \\
\hline $\mathrm{Fe}_{2} \mathrm{O}_{3}-$ iron oxide & 0.66 & 3.99 \\
\hline $\mathrm{P}_{2} \mathrm{O}_{5}-$ phosphorous pentoxide & 0.49 & 0.37 \\
\hline $\mathrm{K}_{2} \mathrm{O}-$ potassium oxide & 0.35 & 1.68 \\
\hline
\end{tabular}


The amorphous nature of the silica was checked with XRD and the results are shown in Figure 3. As expected, there is no change in the amorphous nature with respect to milling time since this process does not occur at high temperatures which could re-arrange the crystallographic structure. As such, there were no observed diffracted peaks of elements and there was a large halo between $20^{\circ}$ and $35^{\circ}$.

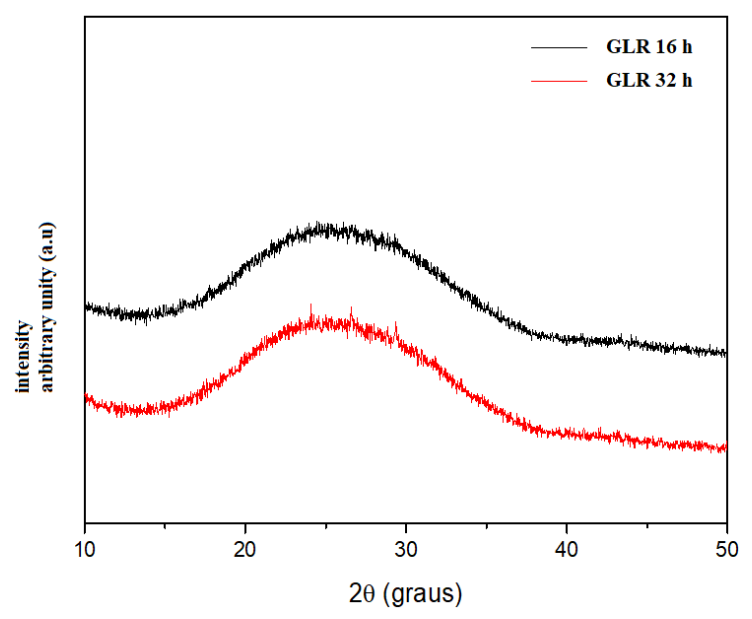

Figure 3. Comparison of XRD of GLR for $16 \mathrm{~h}$ and $32 \mathrm{~h}$ milling time

Pozzolanic activity was evaluated physically in accordance with NBR 5752:2014 [20]. As stated in the norm, a pozzolanic activity index (PAI) of over $90 \%$ must be attained for the material to be considered a pozzolan. In this study, GLR attained PAIs of $103.3 \%$ and $98.5 \%$ for milling times of $16 \mathrm{~h}$ and $32 \mathrm{~h}$, respectively - more than sufficient to establish pozzolanic properties which were later confirmed from chemical tests.

\subsection{Cement characterization}

Figure 4 presents XRD results for Portland cement CP II-Z-32. Diffractogram peaks identified primarily calcium silicate, silicon oxide, calcium carbonate and magnesium oxide, which are all common to Portland cement. The full chemical composition of the cement is presented in Table 4.

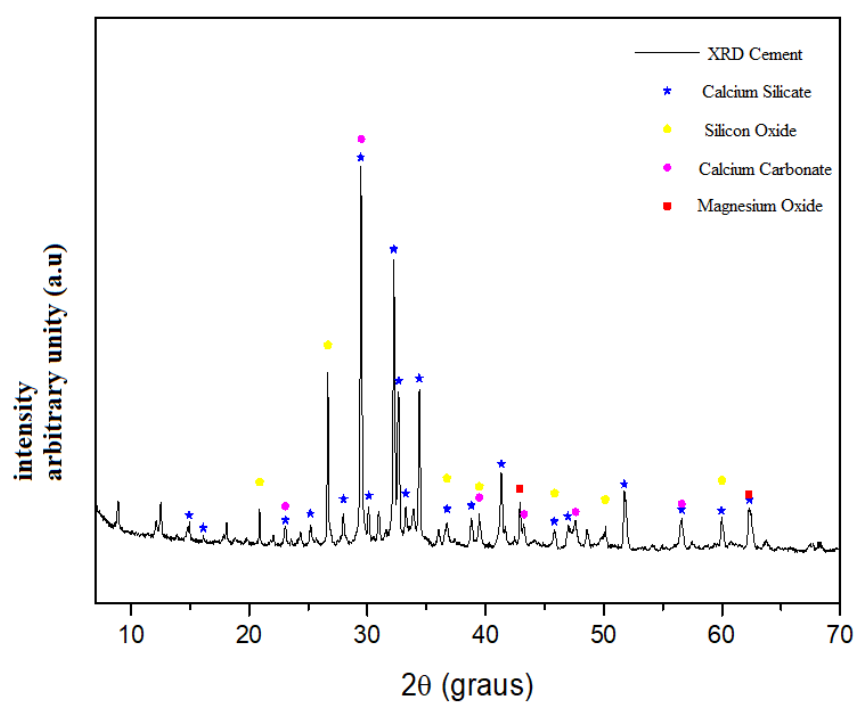

Figure 4. XRD of Portland cement CPII-Z-32 
Cement thermogravimetric results are presented in Figure 5. In the figure, the derivative thermogravimetric curve (DTF) is shown as a red line. The first observed peak occurred at temperatures of less than $200^{\circ} \mathrm{C}$ and was related to interstitial water in the cement. The second peak, observed between $400{ }^{\circ} \mathrm{C}$ and $500{ }^{\circ} \mathrm{C}$, demonstrated the decomposition of a small portion of Portlandite. The third peak, between $600{ }^{\circ} \mathrm{C}$ and $800{ }^{\circ} \mathrm{C}$, was related to the decomposition of calcium carbonate and presented the largest loss in mass of the cement sample. The calcinated mass at the end of the test was of approximately 5 w.t. $\%$ which was similar to the manufacturer's specifications of 5.69 w.t. $\%$ due to heat.

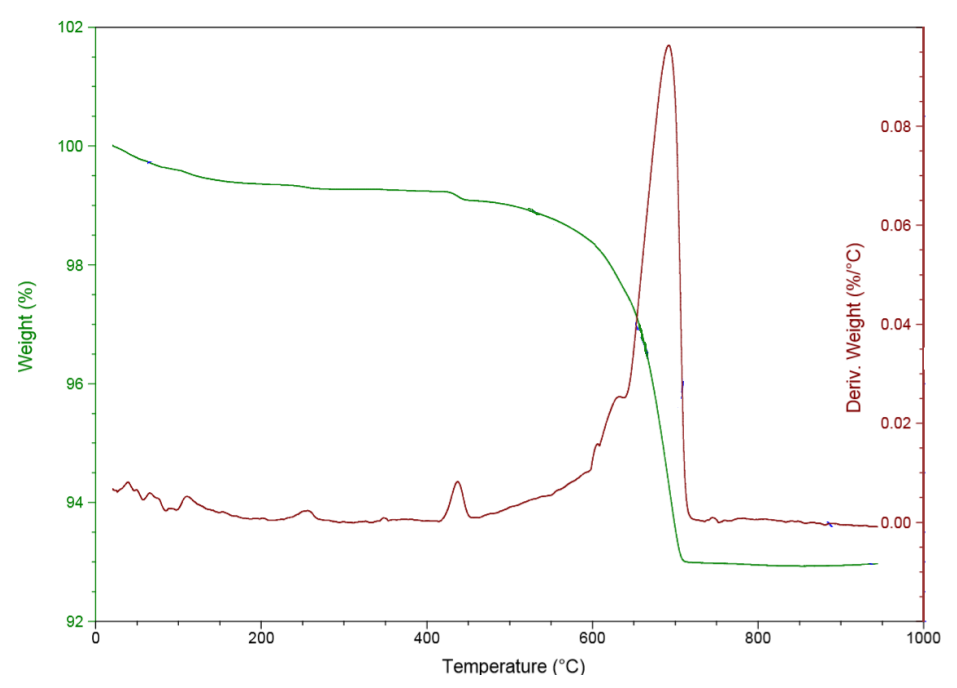

Figure 5. DTF curve of Portland cement CPII-Z-32

\subsection{Alkali-silica reaction tests}

Figure 6 presents the results of expansion tests conducted in accordance with NBR 15577:2018-5 [18] for samples with 10 w.t. $\%, 20$ w.t. $\%, 30$ w.t. $\%$ and 40 w.t.\% GLR substitution for both $16 \mathrm{~h}$ and $32 \mathrm{~h}$ milling times. According to NBR 15577:2018-1 [23], mortar bars samples should not have expansions larger than $0.19 \%$ at 30 days and, as seen in the figure, all samples remained below this threshold. Milling time also did not affect the result which was expected since laser granulometry showed that both cases presented similarly-sized particles.

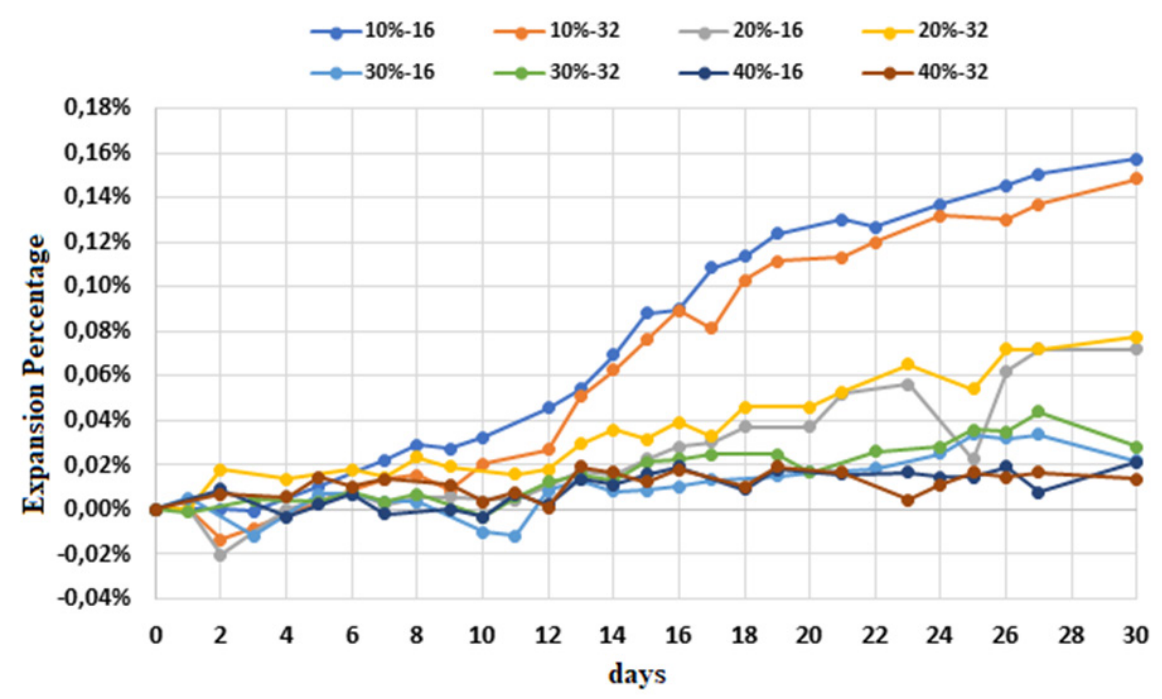

Figure 6. Mortar bars sample expansion with respect to GLR substitution 
Further, as seen in Figure 6, expansion decreased as GLR replacement increased. This was to be expected since, with increasing substitution, the alkali content of the mixture decreased. Also, as noted in other studies, GLR with particle sizes of less than $100 \mu \mathrm{m}$ inhibit alkali-silica reactions (ASR) [24], [17], [19], [25]-[26]. Following this trend, expansions further decreased as substitution increased from 10 w.t.\% all the way to 40 w.t. $\%$. It should be noted that the expansion test in NBR 15577:2018-4 [27] used a control mixture of only CP V cement for comparison purposes with regards to any ASR potential.

\subsection{Axial compression strength of mortars}

Compression strength and spread tests of mortar samples were measured at 7 days and 28 days of curing. Results are presented in Table 5 and shown graphically in Figure 7. It can be noted that compression strength increased for all samples with increasing time.

Table 5. Results of compression strength and spread tests of mortars

\begin{tabular}{cccc}
\hline \multirow{2}{*}{ Mixture } & Compression resistance and standard deviation (MPa) & Spread (mm) \\
\cline { 2 - 3 } & $\mathbf{7}$ days & $\mathbf{2 8 \text { days }}$ & 200 \\
\hline TC & $25.61 \pm 3.32$ & $27.95 \pm 4.35$ & 241 \\
\hline T10A & $21.60 \pm 0.90$ & $24.76 \pm 2.97$ & 246 \\
\hline T10B & $21.21 \pm 1.15$ & $21.76 \pm 2.60$ & 241 \\
\hline T15A & $18.84 \pm 1.23$ & $23.73 \pm 1.92$ & 245 \\
\hline T15B & $17.25 \pm 1.04$ & $21.16 \pm 4.13$ & 259 \\
\hline T20A & $18.28 \pm 1.31$ & $25.78 \pm 2.54$ & 225 \\
\hline T20B & $16.33 \pm 1.03$ & $22.95 \pm 3.02$ & \\
\hline
\end{tabular}

Overall, the test control sample (TC) achieved the highest compression strength but, at 28 days, the difference between the substitution samples and test control sample narrowed. This was a consequence of the pozzolanic effect of GLR which produced a substantial gain in strength over time. This effect was observed in other studies such as Ribeiro [28] and Paiva [21], which also measured significant gains in mortars after 7 days and 28 days. Spread tests noted that all samples exceeded the established initial limit of $200 \mathrm{~mm}$ but the samples with GLR substitution had larger spreads than the test control sample.

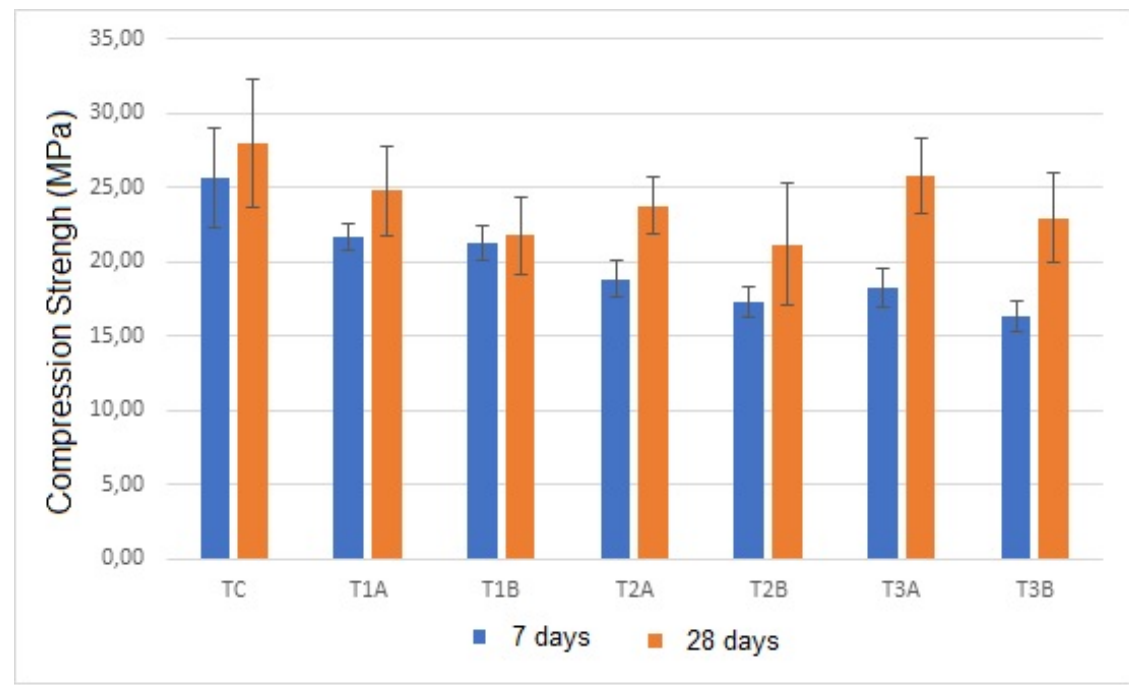

Figure 7. Compression strength of samples at 7 days and 28 days

Further analysis was conducted with ANOVA on Assistant 7.7 commercial software. Factors analyzed were ground time (f1) and w.t.\% GLR substitution (f2) to determine their statistical differences in compression strength tests. 
Table 6 shows the factorial analysis of compression strength for the 7 day case. It can be seen that ground time (factor 1 - f1) as well as w.t.\% substitution (factor 2 - f2) affected resistance significantly.

Table 6. Factor analysis of compression strength at 7 days

\begin{tabular}{ccccc}
\hline VF & DOF & SM & SA & F \\
\hline Factor 1 (f1) & 1 & 12.84456 & 12.84456 & 4.8517 \\
\hline Factor 2 (f2) & 2 & 95.42349 & 47.71174 & 18.0218 \\
\hline Interaction f1 x f2 & 2 & 3.33525 & 1.66762 & 0.6299 \\
\hline Factor x Test Control & 1 & 191.67808 & 191.67808 & 72.4012 \\
\hline Treatment & 6 & 303.28138 & 50.5469 & 5.74840 \\
\hline Residual & 28 & 74.12844 & 2.64744 & \\
\hline Total & 34 & 377.40982 & &
\end{tabular}

Factor 1 (f1) - GLR ground time of $16 \mathrm{~h}$ and $32 \mathrm{~h}$; Factor 2 (f2) - GLR substitution of cement in 10 w.t. $\%$, 15 w.t. $\%$ and 20 w.t.\%.

VF - variation factor; DOF - degrees of freedom; SM - squares sum; SA - squared average; F - F-test statistic.

A Tukey test $(\mathrm{P} \leq 0.05)$ performed on strength data at 7 days led to several observations. Factor 1 presented significant differences as shown in Table 7, with milling time producing differences with respect to the test control sample. But between the milling times of $16 \mathrm{~h}$ and $32 \mathrm{~h}$ there were no significant differences.

Table 7. Tukey test of GLR milling time at 7 days

\begin{tabular}{ccccc}
\hline \multicolumn{5}{c}{ Multiple Comparisons } \\
\hline Level & Center & Lower Limit & Upper Limit & P-value \\
\hline $16-0$ & -6.033333333 & -8.982922991 & -3.083743676 & $5.35652 \times 10^{-5}$ \\
\hline $32-0$ & -7.342 & -10.29158966 & -4.392410343 & $2.28147 \times 10^{-6}$ \\
\hline $32-16$ & -1.308666667 & -3.394341515 & 0.777008182 & 0.285355015 \\
\hline
\end{tabular}

This was to be expected since laser granulometry showed little difference in the particle sizes between both milling times. Factor 2 also displayed statistical difference as shown in Table 8. All substitution mixtures presented statistically different resistances from the test control sample. Mixtures of 15 w.t.\% and 20 w.t.\% substitution also presented differences with respect to the 10 w.t.\% sample but no significant differences were observed between 15 w.t. $\%$ and 20 w.t.\% samples.

Table 8. Tukey test of GLR substitution at 7 days

Multiple Comparisons

\begin{tabular}{ccccc}
\hline Levels & Center & Lower Limit & Upper Limit & P-value \\
\hline $0.1-0$ & -4.202 & -6.73925933 & -1.66474067 & 0.000503383 \\
\hline $0.15-0$ & -7.56 & -10.09725933 & -5.02274067 & $2.30941 \times 10^{-8}$ \\
\hline $0.2-0$ & -8.301 & -10.83825933 & -5.76374067 & $2.98239 \times 10^{-9}$ \\
\hline $0.15-0.1$ & -3.358 & -5.429663568 & -1.286336432 & 0.000657038 \\
\hline $0.2-0.1$ & -4.099 & -6.170663568 & -2.027336432 & $4.23709 \times 10^{-5}$ \\
\hline $0.2-0.15$ & -0.741 & -2.812663568 & 1.330663568 & 0.766864077 \\
\hline
\end{tabular}


The same factor analysis was conducted at 28 days. Table 9 presents ANOVA results with factor 1 and factor 2 having significant impacts.

Table 9. Factor analysis of compression strength at 28 days

\begin{tabular}{|c|c|c|c|c|}
\hline VF & DOF & SM & SA & $\mathbf{F}$ \\
\hline Factor 1 (f1) & 1 & 58.8 & 58.8 & 5.8154 \\
\hline Factor 2 (f2) & 2 & 18.48971 & 9.24485 & 0.9143 \\
\hline Interaction $\mathrm{f} 1 \mathrm{x}$ f2 & 2 & 0.23192 & 0.11596 & 0.0115 \\
\hline Factor x Test Control & 1 & 90.34432 & 90.34432 & 8.9352 \\
\hline Treatment & 6 & 303.28138 & 50.5469 & 2.767 \\
\hline Residual & 28 & 74.12844 & 2.64744 & \\
\hline Total & 34 & 377.40982 & & \\
\hline
\end{tabular}

Factor 1 (f1) - GLR ground time of $16 \mathrm{~h}$ and 32 h; Factor 2 (f2) - GLR substitution of cement in 10 w.t. $\%$, 15 w.t. $\%$ and 20 w.t.\%.

$\mathrm{VF}$ - variation factor; DOF - degrees of freedom; SM - squares sum; SA - squared average; F - F-test statistic.

The Tukey test $(\mathrm{P} \leq 0.05)$ of factor 1 shown in Table 10 presents a statistical difference between the $16 \mathrm{~h}$ milling time and test control sample but no further significant differences with the other cases. The Tukey test $(\mathrm{P} \leq 0.05)$ of factor 2 shown in Table 11 presented statistical differences between the test control sample and 10 w.t. $\%$ and 15 w.t.\% GLR substitution samples. However no significant differences were observed between the test control sample and the 20 w.t.\% GLR substitution sample. No significant differences were also noted in between the various substitution samples.

Table 10. Tukey Test of GLR milling time at 28 days

\begin{tabular}{ccccc}
\hline \multicolumn{5}{c}{ Multiple Comparisons } \\
\hline Levels & Center & Lower Limio & Upper Limit & P-value \\
\hline $16-0$ & -3.191333333 & -7.088629343 & 0.705962676 & 0.125567274 \\
\hline $32-0$ & -5.991333333 & -9.888629343 & -2.094037324 & 0.001835111 \\
\hline $32-16$ & -2.8 & -5.555804437 & -0.044195563 & 0.045817363 \\
\hline
\end{tabular}

Table 11. Tukey Test of GLR substitution at 28 days

\begin{tabular}{ccccc}
\hline \multicolumn{5}{c}{ Multiple Comparisons } \\
\hline Levels & Center & Lower Limit & Upper Limit & 0.067853009 \\
\hline $0.1-0$ & -4.686 & -9.624613052 & 0.252613052 & 0.024373398 \\
\hline $0.15-0$ & -5.502 & -10.44061305 & -0.563386948 & 0.220773465 \\
\hline $0.2-0$ & -3.586 & -8.524613052 & 1.352613052 & 0.946059845 \\
\hline $0.15-0.1$ & -0.816 & -4.848360671 & 3.216360671 & 0.880013391 \\
\hline $0.2-0.1$ & 1.1 & -2.932360671 & 5.132360671 & 0.576250688 \\
\hline $0.2-0.15$ & 1.916 & -2.116360671 & 5.948360671 & \\
\hline
\end{tabular}

Results showed that, at 28 days, milling time was no longer a relevant factor in compression strength - its effect having already occurred at the 7 day point. However, GLR substitutions were relevant both for the 7 day and 28 day periods. The pozzolanic activity of GLR resulted in increases in strength with respect to increasing w.t.\% substitution. 
The sample with the largest substitution (20 w.t.\%) had strength statistically equal to the test control sample. Similar gains in strength due to pozzolanic activity have been observed by Paiva [21] and Ribeiro [28].

\section{CONCLUSIONS}

Ground glass residue (GLR) substitution of Portland cement was demonstrated as a viable alternative, especially since GLR has pozzolanic characteristics. Pozzolanic activity was proven chemically and physically and its use was deemed safe with regards to possible alkali-silica reactions.

Parameters of milling time and w.t.\% substitution of cement with GLR were analyzed with respect to compression strength at 7 days and 28 days of curing. In all samples, strength increased with respect to curing period but the 20 w.t.\% substitution sample obtained the most expressive gains.

Statistical analysis was performed to confirm which factors affected compression strength the most. Results showed that milling times of $16 \mathrm{~h}$ and $32 \mathrm{~h}$ were not significant factors while w.t.\% GLR substitution was responsible for observed effects. In particular, 20 w.t.\% GLR substitution showed no statistical difference in compression strength with respect to the test control sample.

\section{ACKNOWLEDGEMENTS}

The authors express their gratitude to FT/UFAM and IFAM for conducting experimental tests and LAEEM/UNIR for providing laboratory space and technical support.

\section{REFERENCES}

[1] A. M. D. Higuchi, "Estudo do desempenho do resíduo de vidro moído como material cimentício suplementar para aplicação em concreto autoadensável de alto desempenho," M.S. thesis, 2018.

[2] H. A. Abdel-Rahman, M. M. Younes, and M. M. Khattab, "Effect of waste glass content on the physico-chemical and mechanical properties of styrene acrylic ester blended cement mortar composites," Polym. Compos., vol. 39, no. 4, pp. 987-996, 2018.

[3] R. B. C. Sales, F. A. Sales, E. P. Figueiredo, W. J. Santos, N. D. S. Mohallem, and M. T. P. Aguilar, "Durability of mortar made with fine glass powdered particles. Hindawi," Adv. Mater. Sci. Eng., vol. 2017, pp. 1-9, 2017.

[4] J. M. Gómez-Soberón, F. G. Cabrera-Covarrubias, J. L. Almaral-Sánchez, and M. C. Gómez-Soberón, "Fresh-state properties of mortars with recycled glass aggregates: global unification of behavior. Hindawi," Adv. Mater. Sci. Eng., vol. 2018, pp. 1-11, 2018.

[5] N. A. Soliman and A. Tagnit-Hamou, "Partial substitution of silica fume with fine glass powder in UHPC: Filling the micro gap," Constr. Build. Mater., vol. 139, pp. 374-383, 2017. [[Q2: Q2]]

[6] D. Patel, R. P. Tiwari, R. Shrivastava, and R. K. Yadav, "Effective utilization of waste glass powder as the substitution of cement in making paste and mortar," Constr. Build. Mater., vol. 199, pp. 406-415, 2019.

[7] J. Kim, C. Yi, and G. Zi, "Waste glass sludge as a partial cement replacement in mortar," Constr. Build. Mater., vol. 75, pp. 242-246, 2015.

[8] A. R. G. Azevedo, J. Alexandre, E. B. Zanelato, and M. T. Marvila, "Influence of incorporation of glass waste on the rheological properties of adhesive mortar," Constr. Build. Mater., vol. 148, pp. 359-368, 2017.

[9] R. Oliveira, J. Brito, and R. Veiga, "Reduction of the cement content in rendering mortars with fine glass aggregates," J. Clean. Prod., vol. 95, pp. 75-88, 2015.

[10] Associação Brasileira de Normas Técnicas, Agregado Miúdo - Determinação de Massa Específica e Massa Específica Aparente, NBR NM 52, 2009.

[11] Associação Brasileira de Normas Técnicas, Agregados - Determinação da Massa Unitária e do Volume de Vazios, NBR NM 45, 2006.

[12] Associação Brasileira de Normas Técnicas, Agregados - Determinação do Material Fino que Passa Através da Peneira 75 Micrometro, por Lavagem, NBR NM 46, 2003.

[13] Associação Brasileira de Normas Técnicas, Agregado Miúdo - Determinação de Impurezas Orgânicas, NBR NM 49, 2001.

[14] Associação Brasileira de Normas Técnicas, Agregados - Determinação da Composição Granulométrica, NBR NM $248,2003$.

[15] Associação Brasileira de Normas Técnicas, Agregados - Determinação do Teor de Argila em Torrões e Materiais Friáveis, NBR 7218, 2010.

[16] Associação Brasileira de Normas Técnicas, Agregados para Concreto - Especificação, NBR 7211, 2009.

[17] L. M. Sousa No., "Utilização de resíduo de vidro moído como adição mineral para a produção de concreto autoadensável e de alto desempenho," M.S. thesis, Univ. Fed. Amazonas, 2014. 
[18] Associação Brasileira de Normas Técnicas, Agregados - Reatividade Álcali-Agregado - Parte 5: Determinação da Mitigação da Expansão em Barras de Argamassa Pelo Método Acelerado, NBR 15577-5, 2018.

[19] Associação Brasileira de Normas Técnicas, Materiais Pozolânicos - Requisitos, NBR 12653, 2014.

[20] Associação Brasileira de Normas Técnicas, Materiais Pozolânicos - Determinação do Índice de Desempenho com Cimento Portland aos 28 Dias, NBR 5752, 2014.

[21] O. A. Paiva, "Resíduo Industrial de vidro moído em argamassa de cimento Portland,” M.S. thesis, Univ. Fed. Amazonas, 2009.

[22] Associação Brasileira de Normas Técnicas, Argamassa para Assentamento e Revestimento de Paredes e Tetos - Determinação do Índice de Consistência, NBR 13276, 2016.

[23] Associação Brasileira de Normas Técnicas, Agregados - Reatividade Álcali-Agregado - Parte 1: Guia para Avaliação da Reatividade Potencial e Medidas Preventivas para Uso de Agregados em Concreto, NBR 15577-1, 2018.

[24] A. Khmiri, M. Chaabouni, and B. Samet, "Chemical behaviour of ground waste glass when used as partial cement replacement in mortars," Constr. Build. Mater., vol. 44, pp. 74-80, 2013.

[25] Y. Shao, T. Lefort, S. Moras, and D. Rodriguez, "Studies on concrete containing ground waste glass," Cement Concr. Res., vol. 30, no. 1, pp. 91-100, 2000.

[26] R.-U.-D. Nassar and P. Soroushian, "Strength and durability of recycled aggregate concrete containing milled glass as partial replacement for cement," Constr. Build. Mater., vol. 29, pp. 368-377, 2012.

[27] Associação Brasileira de Normas Técnicas, Agregados - Reatividade Álcali-Agregado - Parte 4: Determinação da Expansão em Barras de Argamassa Pelo Método Acelerado - NBR 15577-4, 2018.

[28] A. O. Ribeiro, "Estudo de resíduo de lapidação de vidro para a incorporação em argamassas de cimento Portland,” M.S. thesis, Univ. Fed. Uberlândia, Uberlândia, 2015.

[29] V. Corinaldesi, G. Gnappi, G. Moriconi, and A. Montenero, "Reuse of ground waste glass as aggregate for mortars," Waste Manag., vol. 25 , no. 2, pp. 197-201, 2005.

Author contributions: RKL: conceptualization, supervision, writing, data curation, formal analysis, methodology; JCP: conceptualization, writing; BFT: conceptualization, supervision, writing, data curation, formal analysis, methodology; AEBG: data curation, formal analysis.

Editors: Edgar Bacarji, José Luiz Antunes de Oliveira e Sousa, Guilherme Aris Parsekian. 